\title{
Enhancing the Instructional Delivery of Primary School Teachers through In- Service Training in Nigeria
}

\author{
Edith O. Olorunsola \\ Institute of Education, Ekiti State University, Ado Ekiti, Nigeria
}

\begin{abstract}
This paper investigated the need to enhance instructional delivery of primary school teachers through in-service training for quality instructional delivery in Nigerian primary schools. The paper also examined the status of primary education and highlighted the various strategies by which the government could help in enhancing instructional delivery through in-service training of primary school teachers in order to update their knowledge on the job. It critically examined the status of inservice education of teachers in Nigeria with particular focus on Ekiti State. In Ekiti State, education is highly treasured and given high priority above all things. Parents regard education as an investment and therefore expend their earnings to secure quality education for their children. There is therefore the need to enhance the in-service training needs of teachers at this level to lay a sound foundation for the pupils, and other higher levels of education. It is therefore recommended that if inservice education should be enhanced by the government through seminars, workshops, conferences, resource fellows, lectures, training and re-training programmes, to engender improvement in teacher quality, competence, performance, knowledge and skill updating, methods of teaching as well as innovative ability, particularly in this age of technology.
\end{abstract}

\section{Introduction}

Education is regarded as an instrument per excellence, for affecting national development. It is also seen as a tool to achieving national development. It is through education that ignorance is eliminated, skill for productivity and leadership acquired [16]. The value placed on education explains the high premium placed on it, even in the national policy on education, and the huge investment in it by all stakeholders.

Primary school education is at the base of educational system and therefore constitutes the foundation or bedrock of the nation's new technological and scientific education. The need for enhancing in-service training needs of primary school teachers cannot therefore be under-estimated. A teacher who is not constantly expanding and deepening his knowledge cannot do an adequate job [7]. Quality education is a multi-dimensional concept involving various inputs, process and outcomes [9]. He further stressed that among the indices or inputs for quality education is the teaching force, which must be qualitatively adequate, well educated and professionally prepared, pedagogically skilled and well motivated. Hence the need for enhancing inservice training of teachers so as to encourage total devotion to continuous self improvement on the job, and aiming at providing further knowledge, skills and attitudes to the teacher to improve his performance on the job with a view of promoting quality in education.

Quality education is often linked with such indicators as quality teachers, improved curriculum, good delivery, quality infrastructure, facilities, conducive learning environment, provision of adequate learning materials, training and re-training of teachers, improved teacher - pupil ratio, parental involvement, increased and improved monitoring and superior of learning and quality output among others [6] [8] [15]. Quality in-service education requires quality in-service personnel, requiring professional development of staff [17].

The negative behavioral tendencies as well as the poor qualification of teachers, their role as nation builders and drivers of development remain suspect, as weak teacher will ultimately produce a weak graduate [3].

He commented on the quality of graduates of teacher education institutions and noted that they 'have no strength' with inadequate exposure to teaching practice, lacking in class control and management, shallow in knowledge of their subject 
matter, very weak in communication skills, and lacking in self confidence. It is quite evident and noticeable that among the issues and challenges militating against the smooth and effective implementation of the universal basic education programme in Nigeria are teacher quality, teacher supply and the dearth of teacher professional development programmes [11]. All these call for concern of stakeholders in enhancing in-service training needs of primary school teachers in Nigeria.

In Nigeria's philosophy of education, it is believed that education is an instrument for national development. It also stated that education fosters the worth and development of individual, for each individual's sake, and for the general development of the society hence the need for proper enhancement of in-service need of primary school teachers to lay a formidable foundation for the young ones who will eventually become leaders of tomorrow in our nation.

The quality of instruction at all levels should be toward inculcating the following values:
a. Respect for worth and dignity of the individual.
b. Faith in man's ability to make rational decisions.
c. Moral and spiritual principle in interpersonal and human relations.
d. Shared responsibility for the common good of society.
e. Promotion of the physical, emotional and psychological development of all children, and
f. Acquisition of competences necessary for self- reliance [5].

He further stated that "No education system may rise above the quality of its teachers, and therefore believed that teacher education shall continue to be given major emphasis in all educational planning and development. One could observe that all these are in writing or theory but not in practice in Nigeria.

If education is given high priority by Nigeria government, enhancing the instructional delivery of primary school teachers through in-service education in form of re-training, workshops, seminars, conferences and resource fellows etc. there will be improvement in instructional delivery in schools.

\section{The State of Primary Education in Nigeria}

Primary school education has been bewildered with barrages of problem since independence. The system has undergone series of changes right from the pre-colonial days when the universal primary school education was first introduced in the Western Region of Nigeria in 1955 by late Chief Obafemi Awolowo. The programme was later introduced across the country by General Olusegun Obasanjo in 1976 and was launched as Universal Basic Education (UBE) programme in 1999. All along, the process has been faced with different challenges ranging from input, process and output.

The government has many laudable and novel policies for education at this level, but the problem has remained in proper implementation of such programmes. As long as such problems remain, they pose challenges to the formulated policies. Such problems include political problem, as the management of primary school has shifted from local to state and federal government. The management of primary schools is determined by whoever holds the power at the federal level and this instability in government results in haphazard maintenance and management of the schools, since each preceding or incumbent government may not retain it long enough to implement any meaningful programme before transferring it to a succeeding government.

Also, another major challenge is the learning environment of the pupils. The learning environment is not conducive enough to facilitate effective learning. The state of the schools, which more pupils result in less quality and that many Nigerian primary schools are characterized by dilapidated buildings whose roofs are often blown off during thunderstorms. Pupils gather under tree shades in open fields for their lessons in some village schools. Such schools are characterized by inadequate seats in the classrooms for pupils. Some sit on bare floor, some standing while three or more pupils sit on long rickety benches to learn. One begins to wonder whether such an environment is capable enough to facilitate learning [2].

He corroborated the above and observed that education in Nigeria is besieged by colossal problems such as poor funding, poor educational infrastructure 
including inadequate classrooms, unqualified teachers and polluted learning environment [10]. The poor condition of the primary schools is characterized by poorly trained teachers, poor teaching, poor technology and underfunding [1]. All these challenges call for proper enhancement of instructional delivery of primary school teachers through in-service education.

There is need to continuously improve and update the skills and knowledge of teachers through inservice training of teachers for better instructional delivery, in order to respond to a wide range of demands as a result of rapid and ever changing nature of the world. Teachers are the frontline managers in this respect because they are the people who have direct contact with the pupils and who pass across the required knowledge to the pupils, hence the need to equip teachers very well at this foundational level. Improvement of instructions is better enhanced when the government and heads of schools assist teachers to grow intellectually and also encouraging initiatives [13].

Available statistics from Federal Ministry of Education revealed that only $49.96 \%$ of the primary school teachers, nationwide are said to be qualified. States like Bauchi, Jigawa, Zamfara, Yobe and Kastina recorded as low as 24; 27; 30; 31 and 32 percent of qualified teachers respectively [5]. Many teachers' colleges are non-existent again and many of the teachers in the system presently have their certificate through the distance learning programme provided by the National Teachers' Institute. He added that anyone who has participated in the grading of the examination scripts of this crop of teachers will sympathize with the primary education system [14].

Observation has shown that in-service education is either non-existent, and where it existed, it has been provided as short term crash courses only and the activities are often underfunded; the duration of training was too short, and the quality problematic. All these problems culminated in poor instructional delivery as teachers who should be reservoirs of knowledge are not given priority by organizing programmes that could enrich their knowledge, skill, initiatives and improved instructional delivery.

Despite this attention on pre-service training, there are yet indicators that the quality of teachers in our school system leaves much room to be desired
[3]. In addition, he found the teacher quality in terms of educational quality at the primary school levels disturbing.

\section{Strategies to Enhance In-Service education of primary school teachers}

Funding: Underfunding has been the major hindrance to in-service education of primary school teachers in Nigeria. The federal government expenditure for education is below $10 \%$ of its overall expenditure, hence the federal government should involve all stakeholders in the Nigeria economy in funding primary school education. The NonGovernmental Organisations (NGOs) should also be involved together with other establishments that could be taxed, the petroleum trust fund, import and export taxes. If all these are explored and coordinated well, more money could be generated to finance inservice training of primary school teachers for quality instructional delivery.

School Ownership: The private owned schools should be given aids in grants to finance teachers in seminars, workshops or conferences to update teacher's knowledge, skills and performance so that instructional delivery could be enhanced.

Centralized Management: Education should be seen as an essential service to Nigerian citizens and therefore the management of primary school education should be totally taken over by the federal government instead of changing their fatherhood from time to time thereby making the system unstable and inconsistent. If this could be done, there would be an organized way of financing this level of education in a more coordinated way and series of training and retraining programmes should be organized for teachers to cope with the challenges of their work.

Teachers' Specialization: Teachers' specialization is also of importance to instructional delivery in schools. Training of teachers in specific field will enhance better mastery, performance, confidence, and boldness as teachers will be better equipped in their area of specialization instead of being a jack of all 
trade by teaching all the subjects they were not trained for. Effectiveness will also be enhanced.

Teacher/pupil Ratio: This must be well scrutinized and maintained for effectiveness. When a class is sizeable, it will be better managed than a crowd. Class overcrowding in urban primary schools should be checked by training more teachers so that 35 pupils per teacher be maintained to improve quality of teaching which has declined over the years.

Availability of Instructional Materials: This will enhance quality instructional delivery, if teachers are well trained in pedagogical skills, the use of instructional materials will not be new but will be judiciously used to impart knowledge to the pupils. The use of instructional materials will make learning real, and permanent in the pupils. The use of instructional materials make students to be active, interact better with the teacher and promote social interaction among the pupils [12].

Organization of Refresher Course: In-service training of teachers will enable teachers to acquaint themselves with better methods of teaching that can facilitate effective learning. When teachers vary their methods of teaching, it will enable them to cater for individual differences in pupils. When teachers undergo in-service training, they will be able to use the available materials to an advantage of enhancing better instructional delivery.

Motivation: "where effective teachers can be produced through training and skill development, efficiency is a function of human frame of mind and motivation is a necessary requirement for effectiveness" [4]. Implicitly, skill acquisition for teachers may be achieved through training and retraining, regular seminars, conferences and workshops. These can also be achieved through inservice training and staff development. Motivation is a catalyst for effective instructional delivery which can be achieved through good welfare packages. These are good health facilities and services, regular promotion, car and housing loans, payment of salaries and allowances as at when due and good retirement benefits. All these are stimulants to effective instructional delivery.
Re-establishment of all the moribund teacher training institutions: The government should revisit the re-establishment of their former teacher training colleges which served as foundation for training teachers at the primary school level. These institutions were the places where teachers were taught the rudiments of teaching and the acquisition of pedagogical skills.

Appointment of Only Qualified Teachers: With the high population explosion, it is expected that more teachers will be required. The onus is on the government therefore, to select those that can really deliver the stuff. Qualified teachers should be selected on merit only for better instructional delivery.

\section{Conclusion}

The success of primary school education which is the first six years of the 9-year, Universal Basic Education programme is dependent on effective instructional delivery by the teachers, which is a function of the nature and level of their training. If the strategies highlighted in this write up would be used as a guideline by the government and the UBE managers, there would be great improvement in instructional delivery in Nigeria Primary Schools.

\section{References}

[1] Babalola, J.B and Adedeji, S.O (2009), Deregulation of Provision of Education in Nigeria. Truth, Tortoure and Tactics from American Experience". In: O.M Afolayan, (ed) Multiculturalism in the Age of Mosaic; Essay in Honour of Redelph G. Wilson (New York: Nova Science Publishers Inc), 159 - 170.

[2] Bajah, S.T (1999), Re-cycling Education on a Challenge for the Twenty First Century. Guest Lecture at the $90^{\text {th }}$ Anniversary of King's College, Lagos, $18^{\text {th }}$ June.

[3] Ejiogu, G.O (2002), Nigeria Techers Job Attitude and their effects on the employee's lateness. In A.M Ejiogu and R.A.L Alani (eds), Emergent Issues in education.

[4] Fagbamiye, E.O (2000), Teachers Remunerations Conditions Of Service Job Satisfaction Attitudes To Work And Job Performance In Selected Secondary School In Lagos State. A Lead Paper Presented At The Annual 
Conference Of The Nigerian Association For Educational Administration, University Of Illorin (January $30^{\text {th }}-$ February $2^{\text {nd }}$ ).

[5] Federal Republic of Nigeria (2004), National Policy on Education. Lagos; Federal Ministry of Education.

[6] Idowu, A (1985), Managing conflicts in University: A Group Dynamic approach, Illorin Journal of Education, 5, 36-46.

[7] Isichei (1997), Gender Education and SocioEconomic Growth in Nigeria. In Ejiogu (ed) Emergent isssues in Nigeria Education.

[8] Obameata, J.O (1995), Education: An Unprofitable industry in Nigeria. Ibadan: Postgraduate School Interdisciplinary Research Discourse, University of Ibadan.

[9] Obanya, P.A (2007), African Education in the EFA Ibadan: Mosuro Books.

[10] Odia, I.O., and Omofonmwon S.I (2007), Educational System in Nigeria. Problems and Prospect. Journal of Social Science 14(1): 51-56.

[11] Okebukola, O. (2002), The State of University Education in Nigeria. Abuja. National Universities Commission.

[12] Olorunsola, E.O. (2005), Classroom Management Strategies and the Teaching of Yoruba Language in Secondary Schools. Journal of Research in Curriculum Studies, 4(1): 49 - 53 University of Ado-Ekiti.

[13] Omotayo, K.A. (2007), Teacher Quality: An Imperative for Achieving a Worthwhile UBE in Nigeria. Journal of Educational Foundations and Management vol5(1).

[14] Oni, J.O (1995), Educational Resources $1^{\text {st }}$ Edition, Gbemi Sodipo Press Ltd, Abeokuta. ISBN: 978-978-0476, pp 2.

[15] Onocha, C.O (1985), Patterns of Relationship Between Home and School Based Factors and Pupil Learning Outcomes in Bendel Primary Science Project. Unpublished Ph.D Dissertation, University of Ibadan, Ibadan.

[16] Shokunbi, L. (1999), Science, Technology and Nigeria's Tomorrow. The Guardian, Wednesday April 21.
[17] World Bank (2008), No. 128, Curricular, Examinations and Assessment in Secondary Education in Sub-Saharan African. Washington D.C. 20433, USA 